\title{
Brevundimonas basaltis sp. nov., isolated from black sand
}

\author{
Jung-Hye Choi, Min-Soo Kim, Seong Woon Roh and Jin-Woo Bae
}

Correspondence

Jin-Woo Bae

baejw@khu.ac.kr
Department of Life and Nanopharmaceutical Sciences and Department of Biology, Kyung Hee University, Seoul 130-701, Republic of Korea
The genus Brevundimonas was proposed by reclassification of two Pseudomonas species as Brevundimonas diminuta and Brevundimonas vesicularis by Segers et al. (1994). Several species, including Brevundimonas alba, Brevundimonas aurantiaca, Brevundimonas bacteroides, Brevundimonas intermedia, Brevundimonas subvibrioides, Brevundimonas terrae and Brevundimonas variabilis, were transferred from the genus Caulobacter to the genus Brevundimonas (Abraham et al., 1999). At present the genus consists of 16 identified species. Members of the genus Brevundimonas are Gram-negative, have a 61.8-68.7 mol\% G + C content, and are characterized chemotaxonomically by the presence of $\mathrm{C}_{12: 0} 3-\mathrm{OH}$ fatty acids and the presence of ubiquinone $\mathrm{Q}-10$ (Yoon et al., 2006). In this paper, we describe the morphological, biochemical and phylogenetic characteristics of Brevundimonas-like strain $\mathrm{J} 22^{\mathrm{T}}$.

Strain $\mathrm{J} 22^{\mathrm{T}}$ was isolated from black sand from Soesoggak, a coastline surrounded on three sides by basalt, located in the south of Jeju island ( $\left.33^{\circ} 15^{\prime} 16^{\prime \prime} \mathrm{N}, 126^{\circ} 37^{\prime} 52^{\prime \prime} \mathrm{E}\right)$, Korea. It was isolated by the standard dilution-plating method on $\mathrm{R} 2 \mathrm{~A}$ agar at $30{ }^{\circ} \mathrm{C}$ for 3 days. Cell morphology of strain

The GenBank/EMBL/DDBJ accession number for the 16S rRNA gene sequence of strain $\mathrm{J} 22^{\top}$ is EU143355.
$\mathrm{J} 22^{\mathrm{T}}$ was observed by light microscopy (ECLIPSE $80 i$; Nikon). The presence of flagella was also observed using the flagella staining method (Heimbrook et al., 1989). Motility was examined using motility test medium (BBL) and observed as cell growth spreading out from the line of inoculation in the tube. Growth at different temperatures $\left(4,10,15,20,25,30,37\right.$ and $\left.42{ }^{\circ} \mathrm{C}\right), \mathrm{NaCl}$ concentration $(0$, $1,2,3,4,5,6,8,10,12$ and $14 \%, \mathrm{w} / \mathrm{v})$ and $\mathrm{pH}(5.0-10.0$ at intervals of $0.5 \mathrm{pH}$ units) was monitored on R2A agar at $30{ }^{\circ} \mathrm{C}$ for up to 5 days. Growth on tryptic soy agar (TSA), marine agar (MA), nutrient agar (NA), Luria broth (LB) agar (all purchased from BBL) and Caulobacter medium agar (DSMZ Medium 595) was also evaluated (at $30{ }^{\circ} \mathrm{C}$ ). Hydrolysis of DNA and casein was tested using DNase test agar (BBL) and skim milk (BBL), respectively, as described by Atlas (1993). Hydrolysis of cellulose was tested using the method of Gerhardt et al. (1994). Catalase and oxidase activities of the strain were determined in $3 \%(\mathrm{v} / \mathrm{v})$ hydrogen peroxide solution and in $1 \%(\mathrm{w} / \mathrm{v})$ p-tetramethyl phenylenediamine (bioMérieux), respectively. Other enzyme activities and utilization of different carbon sources were assessed using commercial API 20NE and API ZYM kits (bioMérieux) and the Biolog GN2 MicroPlate assay, according to the manufacturers' protocols. 
The 16S rRNA gene sequence of strain $\mathrm{J} 22^{\mathrm{T}}$ was amplified by the colony PCR method with two universal primers for bacteria (Baker et al., 2003). 16S rRNA gene sequence analysis was performed using the BigDye Terminator Cycle Sequencing Ready Reaction kit (Applied Biosystems) and an automated DNA analyser system (PRISM 3730XL DNA analyser; Applied Biosystems) according to the manufacturer's instructions. The 16S rRNA gene sequence of strain $\mathrm{J} 22^{\mathrm{T}}$ was compared with known $16 \mathrm{~S}$ rRNA sequences of other strains of the genus Brevundimonas in the GenBank database (NCBI). The $16 \mathrm{~S}$ rRNA gene sequence of strain $\mathrm{J} 22^{\mathrm{T}}$ was aligned with that of closely related strains of the genus Brevundimonas by the multiple sequence alignment program CLUSTAL_X v.1.83 (Thompson et al., 1997). The phylogenetic relationship between strain $\mathrm{J} 22^{\mathrm{T}}$ and the representative species of the genus Brevundimonas was defined using MEGA 4 (Tamura et al., 2007). The phylogenetic consensus tree was constructed using the neighbour-joining (Saitou \& Nei, 1987), maximumparsimony (Felsenstein, 1981) and maximum-likelihood (Kluge \& Farris, 1969) methods. Genomic DNA was extracted from strain $\mathrm{J}_{2} 2^{\mathrm{T}}$ and eight reference strains, in addition to Escherichia coli $\mathrm{K}-12$ as a calibration reference, according to Sambrook et al. (1989). In order to evaluate the genomic relationships, DNA-DNA hybridizations were performed fluorimetrically using the method of Ezaki et al. (1989) and the improved method proposed by Hirayama et al. (1996) with dry-adsorption immobilization. The G+C contents were determined using the fluorimetric method proposed by Gonzalez \& Saiz-Jimenez (2002) using SYBR Green I and a real-time PCR thermocycler. For fatty acid analysis, cell biomass of strain $\mathrm{J}_{2} 2^{\mathrm{T}}$ and related species was collected from R2A agar plates after incubation for 2 days at $30{ }^{\circ} \mathrm{C}$. Cellular fatty acids were extracted according to the protocol of Sasser (1990). Cellular fatty acid composition was determined by gas chromatography (Hewlett Packard 6890) and the Microbial Identification System.

The colonies of strain $\mathrm{J} 22^{\mathrm{T}}$ were creamy, convex and circular (0.5-2.0 mm diameter) with an entire edge and a smooth surface after 3 days on R2A agar plates at $30{ }^{\circ} \mathrm{C}$. Cells were rod-shaped, Gram-negative, motile and flagellated. Strain $\mathrm{J}^{2} 2^{\mathrm{T}}$ grew at temperatures in the range of 10 $42{ }^{\circ} \mathrm{C}$, with $0-4 \% \mathrm{NaCl}$ and at $\mathrm{pH}$ 5.5-10.0. Optimum conditions for growth of strain $\mathrm{J} 22^{\mathrm{T}}$ were at $30{ }^{\circ} \mathrm{C}, 0 \%$ $\mathrm{NaCl}$ and $\mathrm{pH}$ 7.5. Strain $\mathrm{J}_{2} 2^{\mathrm{T}}$ grew on R2A, Caulobacter medium and LB, but not on MA, TSA or NA. Strain $J 22^{\mathrm{T}}$ was catalase-positive and oxidase-negative. DNA was hydrolysed, but casein and cellulose were not. Physiological and biochemical characteristics of strain $\mathrm{J} 22^{\mathrm{T}}$ and related species of Brevundimonas are shown in Table 1. Additional characteristics are given in the species description below.

As a result of the phylogenetic analysis, strain $\mathrm{J}_{2} 2^{\mathrm{T}}$ was classified within the genus Brevundimonas and, in particular, as highly related to B. alba $\mathrm{CB} 88^{\mathrm{T}}$ (Fig. 1). The $16 \mathrm{~S}$ rRNA gene sequence of $\mathrm{J}^{2} 2^{\mathrm{T}}$ had $98.95-95.96 \%$ similarity to those of other members of the genus Brevundimonas and
Table 1. Physiological and biochemical characteristics that differentiate strain $\mathrm{J} 22^{\top}$ from related species of the genus Brevundimonas

Strains: 1 , strain $\mathrm{J}^{\mathrm{T}}$; 2, B. alba $\mathrm{CB}^{2} 8^{\mathrm{T}} ; 3$, B. lenta DS- $18^{\mathrm{T}} ; 4$, B. variabilis $\mathrm{CB}^{\mathrm{T}} ; 5, B$. kwangchunensis $\mathrm{KSL}-102^{\mathrm{T}} ; 6$, B. intermedia $\mathrm{CB}^{\mathrm{T}} 3^{\mathrm{T}} ; 7$, B. subvibrioides $\mathrm{CB}^{\mathrm{T}}{ }^{\mathrm{T}} ; 8$, B. bacteroides $\mathrm{CB}^{\mathrm{T}} ; 9$, Mycoplana bullata TK0051 ${ }^{\mathrm{T}}$. Data are from this study. Characteristics that were all negative: reduction of nitrates to nitrites, indole production, glucose fermentation, hydrolysis of urea, utilization of arabinose, mannitol, $\mathrm{N}$-acetylglucosamine, potassium gluconate, capric acid, adipic acid, trisodium citrate and phenylacetic acid, arginine hydrolase, $\beta$-glucuronidase, $\alpha$-mannosidase and $\alpha$-fucosidase. All strains were positive for esterase lipase (C8). Symbols: -, negative; +, positive; w, weak reaction.

\begin{tabular}{|c|c|c|c|c|c|c|c|c|c|}
\hline Characteristic & 1 & 2 & 3 & 4 & 5 & 6 & 7 & 8 & 9 \\
\hline \multicolumn{10}{|l|}{ Hydrolysis of: } \\
\hline Aesculin & + & + & + & + & + & + & + & + & - \\
\hline Gelatin & - & + & + & + & - & - & + & + & - \\
\hline \multicolumn{10}{|l|}{ Utilization of: } \\
\hline Glucose & - & - & - & - & + & + & - & - & - \\
\hline Mannose & - & - & - & - & - & + & - & - & - \\
\hline Maltose & - & - & - & - & - & + & - & - & - \\
\hline Malic acid & - & - & - & - & + & - & - & - & - \\
\hline Galactosidase & + & + & - & + & - & - & - & - & - \\
\hline Alkaline phosphatase & $\mathrm{w}$ & - & + & + & + & + & + & + & + \\
\hline Esterase (C4) & $\mathrm{w}$ & + & + & + & + & + & + & - & + \\
\hline Lipase (C14) & + & - & - & - & - & - & - & - & $\mathrm{w}$ \\
\hline Leucine arylamidase & + & + & + & + & + & + & + & - & + \\
\hline Valine arylamidase & + & + & - & - & + & + & + & - & + \\
\hline Cysteine arylamidase & + & - & - & - & - & - & - & - & $\mathrm{w}$ \\
\hline Trypsin & + & - & + & - & + & + & + & + & + \\
\hline$\alpha$-Chymotrypsin & + & - & - & - & $\mathrm{w}$ & + & $\mathrm{w}$ & - & + \\
\hline Acid phosphatase & - & - & + & - & + & + & - & - & + \\
\hline $\begin{array}{l}\text { Naphthol-AS-BI- } \\
\text { phosphohydrolase }\end{array}$ & $\mathrm{w}$ & - & + & - & + & + & $\mathrm{w}$ & $\mathrm{w}$ & + \\
\hline$\alpha$-Galactosidase & + & - & - & - & - & - & - & - & - \\
\hline$\beta$-Galactosidase & - & - & - & - & - & + & - & - & - \\
\hline$\alpha$-Glucosidase & $\mathrm{w}$ & + & + & - & + & + & + & + & + \\
\hline$\beta$-Glucosidase & - & - & - & - & + & + & - & $\mathrm{w}$ & - \\
\hline$N$-Acetyl- $\beta$-glucosaminidase & - & - & - & - & - & + & - & - & - \\
\hline
\end{tabular}

showed highest similarity to those of the type strain $B$. alba $\mathrm{CB}^{\mathrm{T}} 8^{\mathrm{T}}(98.95 \%)$, B. lenta DS- $18^{\mathrm{T}}(98.58 \%)$, B. variabilis $\mathrm{CB}^{\mathrm{T}}{ }^{\mathrm{T}}(98.06 \%)$, Mycoplana bullata TK0051 ${ }^{\mathrm{T}}(97.75 \%)$, B. kwangchunensis KSL- $102^{\mathrm{T}}(97.61 \%), B$. intermedia $\mathrm{CB}^{\mathrm{T}}{ }^{\mathrm{T}}(97.16 \%)$, B. subvibrioides $\mathrm{CB}^{\mathrm{T}}{ }^{\mathrm{T}}(97.05 \%)$ and B. bacteroides $\mathrm{CB}^{\mathrm{T}}(97.04 \%)$. However, DNA-DNA hybridization values between strain $\mathrm{J}_{2} 2^{\mathrm{T}}$ and other Brevundimonas strains were less than $22.2 \%: 22.2 \%$ with B. lenta DS $-18^{\mathrm{T}}, 21.3 \%$ with $B$. kwangchunensis $\mathrm{KSL}-102^{\mathrm{T}}$, $18.6 \%$ with $B$. alba $\mathrm{CB}^{\mathrm{T}} 8^{\mathrm{T}}, 17.9 \%$ with Mycoplana bullata TK $0051^{\mathrm{T}}, 13.8 \%$ with $B$. variabilis $\mathrm{CB} 17^{\mathrm{T}}, 13.6 \%$ with $B$. subvibrioides $\mathrm{CB}^{\mathrm{T}} 1^{\mathrm{T}}, 11.1 \%$ with $B$. bacteroides $\mathrm{CB}^{\mathrm{T}}$ and $8.6 \%$ with $B$. intermedia $\mathrm{CB}_{3} 3^{\mathrm{T}}$. The $\mathrm{G}+\mathrm{C}$ content of the genomic DNA of strain $\mathrm{J}_{2} 2^{\mathrm{T}}$ was $66.3 \mathrm{~mol} \%$, consistent with $\mathrm{G}+\mathrm{C}$ content of other Brevundimonas species, which 


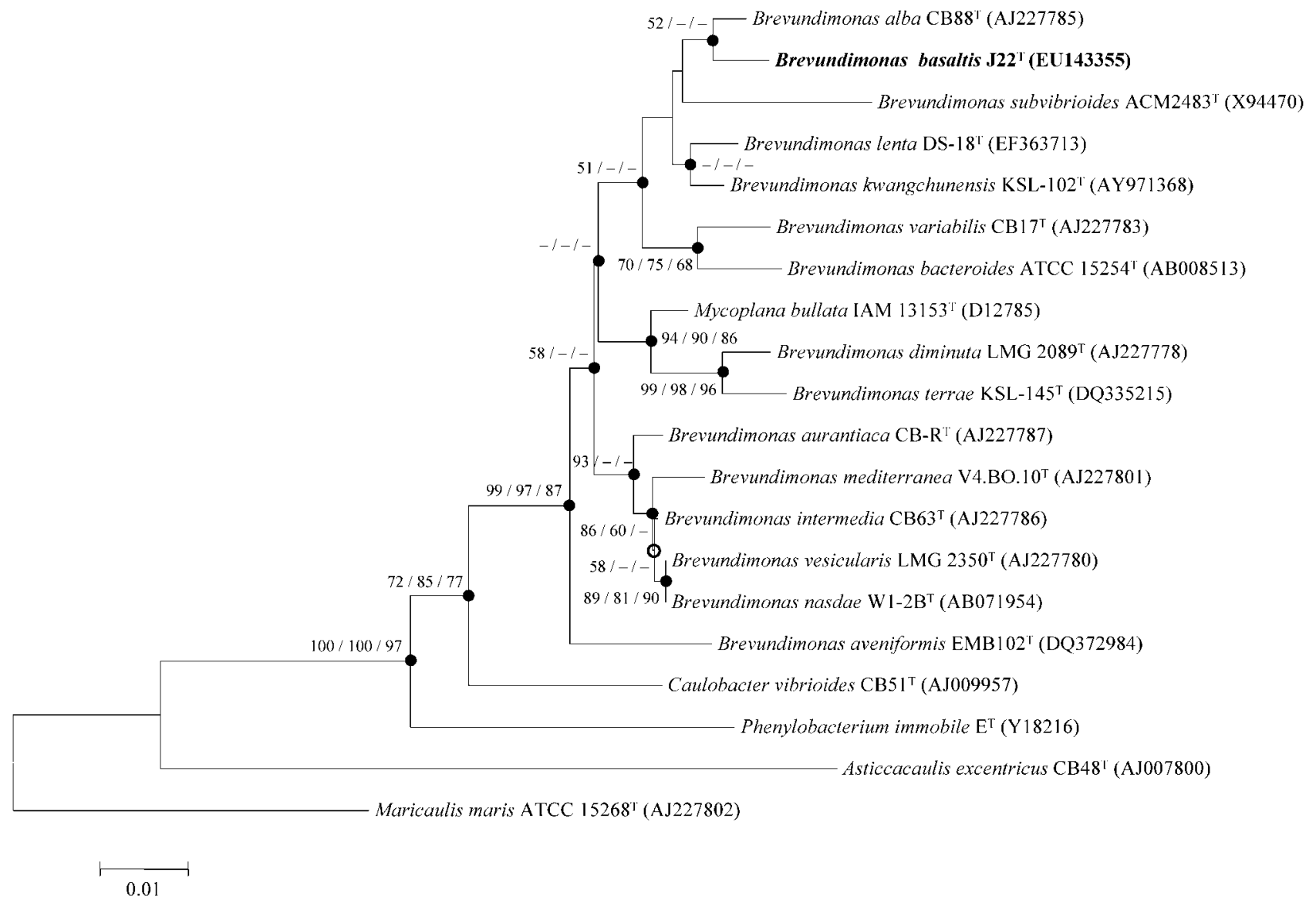

Fig. 1. Phylogenetic consensus tree of strain $J 22^{\top}$ and type strains of related taxa based on $16 \mathrm{~S}$ rRNA gene sequence. The tree was constructed using the neighbour-joining, maximum-parsimony and maximum-likelihood methods and numbers at nodes represent bootstrap values (based on 1000, 1000 and 300 resamplings). Filled circles and the empty circle indicate generic branches that were present among neighbour-joining, maximum-parsimony and maximum-likelihood algorithms, and both neighbour-joining and maximum-parsimony algorithms, respectively. The GenBank accession number of each species is enclosed in parentheses. Maricaulis maris ATCC $15268^{\top}$ was used as the outgroup. Bar, 0.01 substitutions per nucleotide position.

ranges from 61.8 to $68.7 \mathrm{~mol} \%$. The major fatty acids detected in strain $\mathrm{J} 22^{\mathrm{T}}$ were the unsaturated fatty acid $\mathrm{C}_{18: 1} \omega 7 c(46.4 \%)$ and the saturated fatty acid $\mathrm{C}_{16: 0}$ $(19.3 \%)$; the hydroxyl-fatty acid $\mathrm{C}_{12: 0} 3-\mathrm{OH}(2.7 \%)$ was present, which chemotaxonomically characterizes the members of the genus Brevundimonas. The fatty acid profiles of strain $\mathrm{J} 22^{\mathrm{T}}$ and the eight reference strains were very similar. The detailed fatty acid composition is shown in Table 2 .

Strain $\mathrm{J} 22^{\mathrm{T}}$ can be distinguished from related species by lipase (C14) and cysteine arylamidase activity and $\alpha$ galactosidase utilization and differs from $B$. alba $\mathrm{CB} 88^{\mathrm{T}}$ in its non-hydrolysis of casein and cellulose. Strain $\mathrm{J} 22^{\mathrm{T}}$ was classified within the genus Brevundimonas on the basis of 16S rRNA gene sequence and, in particular, as highly related to B. alba $\mathrm{CB}^{2} 8^{\mathrm{T}}(98.95 \%)$. However, DNA-DNA hybridization values between strain $\mathrm{J} 22^{\mathrm{T}}$ and other Brevundimonas strains were less than $22 \%$; the value was $19 \%$ with B. alba $\mathrm{CB}^{2} 8^{\mathrm{T}}$. This showed that its closest phylogenetic relative, $B$. alba, could not be assigned to the same species $(<20 \%)$ (Stackebrandt \& Goebel, 1994). On the basis of the phenotypic, genetic and chemotaxonomic analyses, strain $\mathrm{J} 22^{\mathrm{T}}$ represents a separate novel species of the genus Brevundimonas, for which the name Brevundimonas basaltis sp. nov. is proposed.

\section{Description of Brevundimonas basaltis sp. nov.}

Brevundimonas basaltis (ba.sal'tis. L. masc. gen. n. basaltis of basalt, pertaining to the source of isolation).

Cells are Gram-negative rods and motile via flagella. Colonies are circular, convex, entire, creamy in colour, and $0.5-2.0 \mathrm{~mm}$ in diameter after cultivation for 3 days at $30{ }^{\circ} \mathrm{C}$. Grows at $10-42{ }^{\circ} \mathrm{C}$ (optimum $30{ }^{\circ} \mathrm{C}$ ), with $0-4 \%$ (w/v) $\mathrm{NaCl}$ (optimum $0 \%$ ) and at $\mathrm{pH}$ 5.5-10.0 (optimum $\mathrm{pH}$ 7.5). Growth occurs on R2A, Caulobacter medium and LB. Catalase-positive. DNA and aesculin are hydrolysed, 
Table 2. Fatty acid composition of strain $\mathrm{J} 22^{\top}$ and related reference strains

Strains: 1 , strain $\mathrm{J}_{2} 2^{\mathrm{T}} ; 2$, B. alba $\mathrm{CB}^{\mathrm{T}} 8^{\mathrm{T}} ; 3$, B. lenta $\mathrm{DS}-18^{\mathrm{T}} ; 4, B$. variabilis $\mathrm{CB}_{1} 7^{\mathrm{T}} ; 5$, B. kwangchunensis $\mathrm{KSL}-102^{\mathrm{T}} ; 6$, B. intermedia $\mathrm{CB}^{\mathrm{T}} 3^{\mathrm{T}}$; 7, B. subvibrioides $\mathrm{CB} 81^{\mathrm{T}}$; 8, B. bacteroides $\mathrm{CB}^{\mathrm{T}}$; 9, Mycoplana bullata TK0051 ${ }^{\mathrm{T}}$. Data are from this study. The values are shown as percentages of the total fatty acids. ND, Not detected; tr, trace (less than $1.0 \%)$. All entries of fatty acids found in amounts $<1.0 \%$ are omitted.

\begin{tabular}{|lcccccccccc|}
\hline Fatty acids & $\mathbf{1}$ & $\mathbf{2}$ & $\mathbf{3}$ & $\mathbf{4}$ & $\mathbf{5}$ & $\mathbf{6}$ & $\mathbf{7}$ & $\mathbf{8}$ & $\mathbf{9}$ \\
\hline Saturated & & & & & & & & & \\
$\mathrm{C}_{14: 0}$ & $\operatorname{tr}$ & 1.6 & 3.4 & 3.1 & 2.6 & 2.0 & 5.5 & 3.7 & 1.0 \\
$\mathrm{C}_{15: 0}$ & 3.1 & 2.4 & 5.3 & 2.7 & 5.1 & 4.1 & 4.2 & 2.5 & 3.9 \\
$\mathrm{C}_{16: 0}$ & 19.3 & 22.5 & 22.5 & 19.2 & 21.2 & 21.6 & 18.6 & 13.6 & 20.4 \\
$\mathrm{C}_{17: 0}$ & 1.8 & 1.3 & 1.7 & 2.5 & 1.5 & 3.7 & 1.4 & 1.1 & 1.6 \\
Hydroxy & & & & & & & & & \\
$\mathrm{C}_{12: 0} 3-\mathrm{OH}$ & 2.7 & 1.9 & 2.4 & 2.8 & 2.1 & 3.1 & 2.8 & 2.7 & 1.8 \\
Unsaturated & & & & & & & & & \\
$\mathrm{C}_{15: 1} \omega 8 c$ & 1.5 & $\mathrm{ND}$ & $\mathrm{ND}$ & $\operatorname{tr}$ & $\operatorname{tr}$ & $\operatorname{tr}$ & $\mathrm{ND}$ & $\operatorname{tr}$ & $\operatorname{tr}$ \\
$\mathrm{C}_{16: 1} \omega 9 c$ & 8.1 & 2.4 & $\mathrm{ND}$ & $\mathrm{ND}$ & $\mathrm{ND}$ & $\mathrm{ND}$ & $\mathrm{ND}$ & $\operatorname{tr}$ & $\mathrm{ND}$ \\
$\mathrm{C}_{17: 1} \omega 8 c$ & 4.1 & 3.1 & 3.5 & 3.5 & 3.0 & 2.7 & 2.9 & 3.4 & 3.1 \\
$\mathrm{C}_{17: 1} \omega 6 c$ & $\operatorname{tr}$ & $\mathrm{ND}$ & 1.2 & 1.4 & 1.0 & 1.8 & 1.1 & 2.2 & 1.5 \\
$\mathrm{C}_{18: 1} \omega 9 c$ & 1.3 & 1.7 & $\mathrm{ND}$ & $\mathrm{ND}$ & $\mathrm{ND}$ & $\mathrm{ND}$ & $\mathrm{ND}$ & $\mathrm{ND}$ & $\mathrm{ND}$ \\
$\mathrm{C}_{18: 1} \omega 7 c$ & 46.4 & 37.5 & 39.0 & 57.3 & 36.2 & 39.6 & 54.9 & 60.5 & 50.7 \\
$\mathrm{C}_{18: 1} \omega 5 c$ & 1.8 & 1.1 & $\operatorname{tr}$ & $\operatorname{tr}$ & 1.1 & $\operatorname{tr}$ & $\operatorname{tr}$ & 1.2 & 1.4 \\
$11-\mathrm{Methyl}$ & & & & & & & & & \\
$\mathrm{C}_{18: 1} \omega 7 c$ & 3.3 & 8.5 & 14.0 & $\mathrm{ND}$ & 19.3 & 12.1 & $\operatorname{tr}$ & 1.6 & 2.7 \\
$\mathrm{Cyclo} \mathrm{C}_{19: 0} \omega 8 c$ & $\mathrm{ND}$ & 12.4 & $\mathrm{ND}$ & $\mathrm{ND}$ & $\mathrm{ND}$ & $\mathrm{ND}$ & $\mathrm{ND}$ & $\mathrm{ND}$ & 4.6 \\
Summed feature & & & & & & & & & \\
3 & 2.8 & 3.7 & 5.8 & 4.9 & 5.3 & 5.4 & 5.1 & 4.5 & 4.6 \\
3 & & & & & & & & & \\
\hline
\end{tabular}

${ }^{\star}$ Summed feature 3 contained $\mathrm{C}_{16: 1} \omega 7 c, \mathrm{C}_{15: 0} 2-\mathrm{OH}$ iso.

but casein, cellulose, urea and gelatin are not. Indole is not produced. Positive for activity of esterase lipase (C8), lipase (C14), leucine arylamidase, valine arylamidase, cysteine arylamidase, trypsin, $\alpha$-chymotrypsin and $\alpha$-galactosidase. Negative for activity of acid phosphatase, $\beta$-galactosidase, $\beta$-glucosidase, $N$-acetyl- $\beta$-glucosaminidase, $\beta$-glucuronidase, $\alpha$-mannosidase and $\alpha$-fucosidase, and negative reactions are obtained for utilization of glucose, mannose, maltose, malic acid, arabinose, mannitol, $\mathrm{N}$-acetylglucosamine, potassium gluconate, capric acid, adipic acid, trisodium citrate and phenylacetic acid (API 20NE and API ZYM). Utilizes dextrin, $\beta$-hydroxybutyric acid, $\alpha$ ketoglutaric acid, quinic acid, L-alaninamide and L-aspartic acid (Biolog GN2). Other organic substrates are not utilized. Major fatty acids are $\mathrm{C}_{16: 0}(19.3 \%)$ and $\mathrm{C}_{18: 1} \omega 7 c(46.4 \%)$. The DNA G $+\mathrm{C}$ content is $66.3 \mathrm{~mol} \%$.

The type strain, $\mathrm{J} 22^{\mathrm{T}}\left(=\mathrm{KCTC} 22177^{\mathrm{T}}=\mathrm{JCM} 15911^{\mathrm{T}}\right)$, was isolated from black sand taken from Soesoggak Beach on Jeju, Republic of Korea.

\section{Acknowledgements}

We thank Dr J. P. Euzéby (École Nationale Vétérinaire, France) for etymological advice. This work was supported by the CAER (Center for Aquatic Ecosystem Restoration) of the Eco-STAR project, the 21C Frontier Microbial Genomics and Application Center Program, the Eco-technopia 21 project and the Environmental Biotechnology National Core Research Center (KOSEF: R15-2003012-02002-0).

\section{References}

Abraham, W.-R., Strompl, C., Meyer, H., Lindholst, S., Moore, E. R., Christ, R., Vancanneyt, M., Tindall, B. J., Bennasar, A. \& other authors (1999). Phylogeny and polyphasic taxonomy of Caulobacter species. Proposal of Maricaulis gen. nov. with Maricaulis maris (Poindexter) comb. nov. as the type species, and emended description of the genera Brevundimonas and Caulobacter. Int J Syst Bacteriol 49, 1053-1073.

Atlas, R. M. (1993). Handbook of Microbiological Media. Edited by L. C. Parks. Boca Raton, FL: CRC Press.

Baker, G. C., Smith, J. J. \& Cowan, D. A. (2003). Review and reanalysis of domain-specific $16 \mathrm{~S}$ primers. J Microbiol Methods 55, 541555 .

Ezaki, T., Hashimoto, Y. \& Yabuuchi, E. (1989). Fluorometric deoxyribonucleic acid-deoxyribonucleic acid hybridization in microdilution wells as an alternative to membrane filter hybridization in which radioisotopes are used to determine genetic relatedness among bacterial strains. Int J Syst Bacteriol 39, 224229.

Felsenstein, J. (1981). Evolutionary trees from DNA sequences: a maximum likelihood approach. J Mol Evol 17, 368-376.

Gerhardt, P., Murray, R. G. E., Wood, W. A. \& Krieg, N. R. (1994). Methods for General and Molecular Bacteriology. Washington, DC: American Society for Microbiology.

Gonzalez, J. M. \& Saiz-Jimenez, C. (2002). A fluorimetric method for the estimation of $\mathrm{G}+\mathrm{C}$ mol\% content in microorganisms by thermal denaturation temperature. Environ Microbiol 4, 770773.

Heimbrook, M. E., Wang, W. L. \& Campbell, G. (1989). Staining bacterial flagella easily. J Clin Microbiol 27, 2612-2615.

Hirayama, H., Tamaoka, J. \& Horikoshi, K. (1996). Improved immobilization of DNA to microwell plates for DNA-DNA hybridization. Nucleic Acids Res 24, 4098-4099.

Kluge, A. G. \& Farris, F. S. (1969). Quantitative phyletics and the evolution of anurans. Syst Zool 18, 1-32.

Saitou, N. \& Nei, M. (1987). The neighbor-joining method: a new method for reconstructing phylogenetic trees. Mol Biol Evol 4, 406425.

Sambrook, J., Fritsch, E. F. \& Maniatis, T. (1989). Molecular Cloning: a Laboratory Manual, 2nd edn. Cold Spring Harbor, NY: Cold Spring Harbor Laboratory.

Sasser, M. (1990). Identification of bacteria by gas chromatography of cellular fatty acids. MIDI Technical Note 101. Newark, DE: MIDI.

Segers, P., Vancanneyt, M., Pot, B., Torck, U., Hoset, B., Dewettinck, D., Falsen, E., Kersters, K. \& De Vos, P. (1994). Classification of Pseudomonas diminuta Leifson and Hugh 1954 and Pseudomonas vesicularis Busing, Doll, and Freytag 1953 in Brevundimonas gen. nov. as Brevundimonas diminuta comb. nov. and Brevundimonas vesicularis comb. nov., respectively. Int J Syst Bacteriol 44, 499-510.

Stackebrandt, E. \& Goebel, B. M. (1994). Taxonomic note: a place for DNA-DNA reassociation and $16 \mathrm{~S}$ rRNA sequence analysis in the present species definition in bacteriology. Int J Syst Bacteriol 44, 846849. 
Tamura, K., Dudley, J., Nei, M. \& Kumar, S. (2007). MEGA4: Molecular Evolutionary Genetics Analysis (MEGA) software version 4.0. Mol Biol Evol 24, 1596-1599.

Thompson, J. D., Gibson, T. J., Plewniak, F., Jeanmougin, F. \& Higgins, D. G. (1997). The CLUSTAL_X windows interface: flexible strategies for multiple sequence alignment aided by quality analysis tools. Nucleic Acids Res 25, 4876-4882.

Yoon, J.-H., Kang, S.-J., Oh, H. W., Lee, J.-S. \& Oh, T.-K. (2006). Brevundimonas kwangchunensis sp. nov., isolated from an alkaline soil in Korea. Int J Syst Evol Microbiol 56, 613-617. 